DOI: 10.19085/journal.sijbpg030401

\title{
The Efficacy of Nigeria Monetary Policy: A Comparative Analysis
}

\author{
${ }^{1}$ Acha Ikechukwu \& ${ }^{2}$ Ikoh Itoro \\ ${ }^{1,2}$ Department of Banking and Finance University of Uyo, Uyo, Akwa Ibom State, Nigeria. \\ ${ }^{3}$ Nsien Christiana \\ ${ }^{3}$ Department of Business Education, College of Education, Akwa Ibom State, Nigeria.
}

(c) Scholedge International Journal of Business Policy \& Governance (ISSN 2394-3351), Vol.03, Issue 04 (2016) pg51-62. Published by: Scholedge R\&D Center [www.theSCHOLEDGE.org] [Email: editorial@thescholedge.org]

\begin{abstract}
This study assesses the efficacy of the Nigeria's monetary policy against the backdrop of single digit inflation monetary policy target of the regulatory authorities. Two related questions were constructed to guide the study. Relying on both the Keynesian and Structuralist analyses, data were harvested on inflationary performance for 24 years on Nigeria economy from the World Bank data base and assessed it against achievement of the targeted single digit inflation. Thereafter Nigeria inflationary performance was compared with that of South Africa another leading African economy. It was realized that inflationary pressure on the South African economy was lower than that of Nigeria, even when both countries faced high inflation episodes during the early decade of 1990s. Findings which confirm the structuralist's argument revealed that factors beyond the purview of monetary policy constrained the realization of single digit inflation. These include the existence of various and uncontrolled sources of liquidity in the country, government fiscal operation, which include financing of deficit budget and monetization of deficits, the existence of large informal credit markets, among others. Based on this, we recommend for concerted improvement of public infrastructure, the perfection of cashless economy programme, effective prosecution of war against corruption, and the creation of a single treasury account to help close leakages especially those linked to revenue accruable to government through MDAs and remittance to States and MDAs, among others.
\end{abstract}

Key words: Inflation, Structuralist, Keynes, Single treasury account, South Africa

\section{Introduction}

Monetary policy is the process by which the monetary authority of a country controls the supply of money. Ordinarily, the involvement of the two key words, policy and process, suggests the availability of meticulous guidelines, a plan of action agreed upon or adopted (Ikoh, 2010) to influence the control of fund by the monetary authority; while process refers the employment of variety of tools in order to achieve the result (Altman, 2003). In general terms therefore, Nnanna (2001, p. 3) referred to monetary policy as "a combination of measures designed to regulate the value, supply and cost of money in an economy, in consonance with the expected level of economicactivity". Monetary policy therefore is not without set objectives. It is the achievement of these objectives that inform the importance of monetary policy.

In Nigeria, the $\mathrm{CBN}$ is vested with the powers to promote and maintain monetary stability and sound financial system (CBN Act, 1958). Specifically, the objectives of monetary policy include, achievement 
of domestic price and exchange rate stability; maintenance of a healthy balance of payments position; development of a sound financial system; and promotion of rapid and sustainable rate of economic growth and development (Nnanna, 2004).In other to carry out the monetary policy component, the CBN constitutes the Monetary Policy Committee (MPC) that meet regularly to evaluate the performance of the economy and take decisions aims at curtailing inflation, maintain internal and external balance of payment, as well as exchange rate stability (Omotola, 2013). In doing these a broad range of policy instrument ranging from Monetary Policy Rate (MPR), Open Market Operation (OMO), Cash Reserve Ratio (CRR), Liquidity Ratio, to treasury Securities are used.The extent to which the combination and mix of these instruments are used to stabilize prices of goods and services influences the success of monetary policy.

The ability to correctly measure and understand what monetary policy can do (as well as what it cannot do) is essential for good policy-making and for choosing among alternative macro-economic frameworks (Chuku, 2009). Relying on that argument, Altman (2003) concluded that the issuance of monetary policies by the CBN has not been efficacious in the achievement of intended purpose. Many other scholars have blamed domestic price fluctuation as factors that undermine the success of monetary policies (Fasanya, Onakoya, \&Agboluaje 2013; Adeoye, Ojapinwa, \&Odekunle, 2014) and frustrates investments and growth (Aliyu\&Englama, 2009). Extant literature reporting empirical studies conducted by Ajayi and Ojo (1981) as well as Fischer (1993) on inflation, growth and productivity has confirmed the existence of inverse relationship between inflation and growth. When Nnanna decomposed growth into several components, viz: growth due to capital accumulation, productivity growth, and the growth rate of the labour force, and assessed a relationship between them and inflation, he found a strong negative relationships between them, and thus concluded that stable prices were essential for growth (2001). In another study, Balolgun (2007) tested the hypothesis of monetary policy ineffectiveness in Nigeria and found that rather than promote growth; erstwhile domestic monetary policy was the source of stagnation and persistent inflation. Taylor (2004) thus argued that inflation is harmful to economic growth, as it creates volatility and raises interest rates, while reducing private investment.Much as these empirical findings are persuasive, and are based on grounded arguments "that increase in the quantity of money that is not associated with corresponding increases in real output will eventually lead to inflation; and that a shortage of money can depress the volume of economic activity" (Aliyu \& Englama, 2008), they failed to explain the extent of the performance failure of Nigeria's monetary policy, thus leaving readers in the dark as to whether the periodic monetary policy made no achievement at all.

By definition, price stability in Nigeria refers to the achievement of a single-digit inflation rate on an annual basis (Nnanna, 2001). The performance of Nigeria's monetary policy framework, therefore, can be assessed according to the extent to which the actual growth in monetary aggregates, GDP growth rate and inflation, approximate the policy targets. Using this yardstick, the outcome of monetary policy in Nigeria may indeed be generally mixed.In his recent analysis, Omotola (2013) compared the performance of Nigeria monetary policy with that of Ghana and Kenya, and concluded that Nigeria's performance was better. However much as these countries are in Sub-Saharan Africa, it would be wrong to conclude that Nigeria and Ghana are similarly exposed to the inflow of roving private equity capital driven by globalization. A comparison with a country in similar economic footing like Nigeria will reveal the extent to which monetary policy has been used to combat inflation, and the constraints (if any) that prevent successful realization of monetary policy objective.

Recently, Taylor (2013) observed positive development in theachievement of the South African monetary policy; not only does inflation rate dropped from 7.1 percent in 2009 to 5.1 per cent in 2013, but has also remained consistently around 5 percent for the past five years. In terms of economic development both Nigeria and South Africa are developing countries whose economies are well integrated with the global economy with developed financial markets and huge foreign participation. Comparing the performance of Nigeria monetary policy with that of South Africa will help us to 
understand how the CBN has faired in overcoming the challenges to tame inflation and ensuring the purchasing power of Nigerians does not weaken. It will also help in exposing the factors behind inflationary pressures in Nigeria economy. In order to realize this purpose the paper asked two related questions:

i. Given the $\mathrm{CBN}$ inflationary score-card, has monetary policy been effective in taming inflation?

ii. What are the factors that constitute constraints to the realization of Nigeria monetary policy compared to South Africa?

It is arguable that the efficacy of the monetary policy can be judged by its ability to achieve its target objectives. The Keynesians have argued that monetary policy affects money supply, as changes in interest rate seek to balance demand with supply (Rogoff, 1955; Okigbo, 2008). The changes in interest rates then affect investment and consumption which latter cause changes in output and eventually prices (Ndekwu, 2005). While monetary policies are at best reactionary, scholars have pointed to the fact that inflation is not only due to the quantum of money supplied into the economy, but also a result of structural problems which is beyond monetary policy (Omotola, 2013). When people find barriers in their path, they usually find a way to circumvent or reduce the impact of the impact of those barriers. This usually created unintended consequences (Miles, Holmes \& O'Grady, 2006). Relying on both the Keynesian's and Structuralists' observations, we argued that the indirect effect of money on other economic variables affects investment and cash holding of economic agents. Such effects can be negative if it results in uncontrolled inflation.

The significance of the paper is anchored on its comparative stance. Much as the performance of monetary policy framework can be assessed on the extent to which the actual growth in monetary aggregates, GDP growthrate and inflation, have been achieved using the targeted objective as measurement guide, we reasoned that inflation rate has been used to conclude arguments on price stability and economic stabilization (Soludo, 2001, cited in Nnanna, 2001). As Miles et al (2006) argued, a good way to gauge the influence of monetary policy on price stability and economic stabilization is to analyze the inflation rate over a period of time. The advantage of using comparative terms to evaluate the performance of Nigeria's monetary policy in combating inflation is that it would enable us to realize those factors inherent in our environment (structural factors) that hinder the realization of monetary policy objectives. Such realization would help in suggesting effective solutions.

The paper is structured in themes, beginning with the introduction. The rest of the paper is dedicated to conceptual explanation, review of related literature, and theoretical consideration. In the next theme we explained the methodology used in data collection; thereafter, we present the analysis by way of comparing performance of inflation in Nigeria and South Africa. Following this is a discussion of our findings. The paper ends with discussion, conclusion and recommendation.

\section{Conceptual clarification and literature review}

Monetary policy has been defined as a combination of measures designed to control the supply of money and credit conditions in an economy (Okigbo, 2008). The value of money a country has is shaped largely by the monetary policy of government. This observation suggests that monetary policy rests on the relationship between the rates of interest (that is, the price at which money can be borrowed), and the total supply of money, in an economy (Okigbo, 2008). In Miles et al (2006, p. 65) observation, "a stable monetary policy enable people to rely on market prices for the foreseeable future". In this context investment, savings and other longer-term plan can be easy to make.

Monetary policy measure involves a variety of policy instruments, such as the Monetary Policy Rate (MPR), Open Market Operation (OMO), Cash Reserve Ratio (CRR), Liquidity Ratio, Treasury Securities, etc. Monetary policy may be expansionary or contractionary. An expansionary monetary policy seeks 
to increase the total supply of money in the economy more rapidly than usual, while a contractionary monetary policy expands the money supply more slowly than usual or even shrinks it (Friedman, 2001). In Mankiw's (2002) analysis, expansionary monetary policy is traditionally used to combat unemploymentin a recession by lowering interest rates in the hope that easy credit will entice businesses into expanding. Contractionary policy is intended to slow inflation in order to avoid the resulting distortions and deterioration of asset values.In the work of Lipey and Chrystal (1995), inflation is regarded as a generalized increase in the level of price sustained over a long period in an economy. This definition shares similarity with that of Umaru and Zubairu (2012), who referred to inflation as a "persistence rise in the general price level of broad spectrum of goods and services in a country over a long period of time". Inflation, therefore, is intrinsically linked to money much money chasing too few goods.

Inflation rate is primarily measured as the percentage change in the consumer price index (CPI). The $\mathrm{CPI}$ measures the price of the representative food and services components such as food, alcoholic beverages, energy, housing, clothing, transport, health, communication, transport, etc (Omotola, 2013). In Nigeria, the consumer price inflation captures the movement in the prices of essential commodities and service that reflect the welfare of the citizens. The argument on consumer price inflation tends to be polarized between the Neoliberal/Monetarists and the Structuralist schools. While the neoliberal/monetarist proponents see the quantum of money supplied as the primary drivers of inflation, the Structuralists point to problems located in institutions, public utilities and infrastructure, security, corruption, goods hoarding and hedging, etc, as causes of inflation.

Beside the neoliberal/monetarist and structuralists argument, factors causing inflationary pressures in Nigeria can be located in the forces of demand and supply. Despite effort to grow the agricultural and the solid mineral sectors, Nigeria still depend primarily on crude oil for revenue. In this context, oil prices and it vagaries, detect goernment expenditure (Ikoh \& Ukpong, 2010). Whenever the takings from oil are high,government expenditure is heightened. In recent years the Federal Government fiscal expenditure has increased steadily from just a little over $\mathrm{N} 1$ trillion in 2001 (57\% recurrent) to over $\mathrm{N} 4$ trillion in the 2012 fiscal year (recurrent now over 70\%) (Omotola, 2013). The monthly release of money to component States in the federation and massive expenses that followed, escalates domestic consumption, most of which cannot be be met by domestic production. These monthly build up of excess liquidity, lack of viable manufacturing sector to meet the demand of the citizens, expose the economy to imported inflation.

Historically, monetary policy as a technique of economic management can be traced back to the time of Adam Smith, who championed the explanation on how money affects economc aggregates. Since then the role of monetary policy in influencing macroeconomic objectives like economic growth, price stability, etc, has been severally explored. In Nigeria, Nnanna (2001) documented the evolution of the monetary policy framework ranging from the exchange rate targeting regime (1959 - 1973), direct control (1974 - 1992), monetary targeting regime (1974 - date), to indirect monetary control. In all these, the instrument of OMO is being complemented by those of reserve requirements, viz; Cash Reserve Ratio (CRR) and Liquidity Ratio (LR), for the purpose of maintaining price stability and promotes non-inflationary growth (Omotola, 2013). Several scholars have documented the manipulation of these instruments (Ndekwu, 2005, Johnson, 2009) and the subsequent effect on financial market (Ajayi\&Atanda, 2012), as well as the operation technicalities of OMO (Alade, 2003; Enahoro, et al, 2013).

While acknowledging the efficacy of monetary instruments, Enahoro, Yayeola and Onou (2013) observed that monetary policy can only be credible to the extent that the policy-makers are also credible. In Nigeria, the Monetary Policy Committee meets periodically to reviewed the global and domestic economic environment and assessed the short- to medium-term risks to inflation, domestic output and financial stability. Base on the outcome of the meeting policy decisions are taken and announcement made. In this context policy makers must be seen to have taken decisions that 
participating banks and financial houses believe will reflect actual future policy. If an announcement about low-level inflation targets is made but not believed by private agents, wage-setting will anticipate high-level inflation and so wages will be higher and inflation will rise. A high wage will increase a consumer's demand (demand pull inflation) and a firm's costs (cost push inflation), so inflation rises (Rogoff, 1985).

While scholarly debate exist on the exact meaning of credibility as it relates to monetary policy (Rogoff, 1985; Friedman, 2001), others have argued that the existence of an independent Central Bank with a commitment to policy goal can send a credible message (Forder, 2004; Onyeiwu, 2012). In Chuku's (2009, p.114) explanation "credibility refers to the level of commitment of the central bank to following a set down monetary policy rule rather than following a discretionary approach". This is because economic agents often forecast expected monetary policy, and following such forecast decisions are taken. In this context reputation of the CBN would play a crucial role in determining how much markets would believe in the periodic announcement of the Monetary Policy Committee that the policy is made to serve the interest of the public. In their contribution, Busari, Omoke and Adesoye (2002) argued that monetary policy would better stabilize the economy if it is used to target inflation directlythan be used to directly stimulate growth. They advised that other policy measures and instruments are needed tocomplement monetary policy in macroeconomic stabilization.

In his analysis of financial innovation and monetary control in Nigeria, Koger (1995, cited in Onyeiwu, 2012) observed that the CBN cannot realize the objective of the monetary policy because profit seeking financial institutions often change or create newinstruments in order to evade regulations. Nnanna (2001, p.11) agreed with this position. According to him, "monetary management in Nigeria was relatively more successful during the period of financial sectorreform which was characterized by the use of indirect rather than direct monetary policy tools". He observed however, incessant political interference, fiscal dominance and laxity in the legalenvironment in which the Central Bank operated.This finding suggests that the effectiveness of CBN's monetary policy in combating price stabilization and inflation can be sabotaged by other structural factors.

\section{Theoretical consideration}

The theoretical justification for monetary policy has remained that of price stability and sustainable economic growth. Associated objectives include full employment and stable long-term interest rates and real exchange rates. The position of Keynes is that unemployment arises from inadequate aggregate demand which can be increased by expansionary monetary policy. Increase in money supply will increase spending, increase employment and economic growth. But these achievements are not without unintended constraints. The neoliberal/monetarists argument is that the quantum of money supply released into the economy primarily drives inflation which is harmful to economy growth (Friedman, 1968). Inflation would not only consfiscate wealth, but also distorts pricing, misallocate resources, raises the cost of doing business, and undermines a free society (Miles, et al, 2006). Even though some evidence suggests that moderate inflation helps in economic growth (Ndekwu, 2005), the overall weight of evidence so far clearly indicated that inflation is inimical to growth (Fasanya et al, 2013; Adeoye et al, 2014). Expanding the economy to create wealth without causing inflation becomes the preoccupation of monetary policy authority.

In Keynesian analysis, change in money stock facilitates activities in the financial market thus affecting interest rate, investment, output and employment. Removing spending from the economy will reduce levels of aggregate demand and contract the economy, thus stabilizing prices (Borio, 1995) several scholarly arguments have followed the Keynesian principle. For instance, Modigliani, (1963) argued that only when financial intermediaries are made to enforce the policy would the effect be felt. Additionally, Oliner and Rudebush (1995) observed that when the economy is contracted and the interest rate increased, small firms are crowed out of business. In pursuing the objective of a balance economy, the monetary authority recognizes the existence of conflicts among operating agents (banks and financial institutions) which at some points can cause distortions in achieving set goals. For 
instance, the $\mathrm{CBN}$ targets of monetary policy include the operational target, the intermediate target and the ultimate targets. The Bank manipulates the operating target (reserve money) over which it has substantial direct control to influence the intermediate target (broad money supply, $\mathrm{M}_{2}$ ) which in turn impacts on the ultimately or final objective of monetary policy, i.e., inflation and output (Ajayi, 1999). Given this circumstance, Fischer (1997), that better regulation and supervision are key to compliance with monetary policy guidelines. "Supervision requires the monitoring and enforcement of monetary policy guidelines" and this task is rarely asit sounds. This is because effective supervision will require constant monitoring, probing, analyzing and questioning banks' activities and data. Within this context, the direct resource cost could be large especially if staffs with appropriate qualifications are not available.

Besides, the Structuralists argued that factors that contrained the realization of Nigeria's policy objectives are imbedded in the Nigeria social structure (Omotola, 2013). Such factors include security, corruption, goods hoarding and hedging, etc.All these exert negative impact on the capacity of the manufacturing sector, which have exposed the country to imported inflation and external commodities price shocks. This supply side inflationary factor which relates to exchange rate movement on the domestic price level has increasingly been a source of worry to monetary policy makers.

The dependent on oil price reflects a structural factor. In the event of a drop on oil price, the country's revenue earning also drop, with a consequent impact on foreign reserve and exchange rate of the Naira. Another factor that drives inflationary pressures is the security situation in the country; with many farmers being displaced from their farms, there is a shock in food and energy prices which mount to inflationary pressure on the consumer price index (Adeoye, Ojapinwa\&Odekunle, 2014). Other than this increase spending on security intervention has a downside effect on inflation and the exchange rate.Combating these structural problems appear to lie beyond the scope of monetary policy.

\section{Methodology}

This study relies on secondary data drawn from the National Bureau of Statistics and the World Bank.The World Bank data base contained record of different countries inflation rating and ranking. From the data base we harvested records for Nigeria and South Africa ranging from 1961 to 2013. But for the purpose of comparison we restrict it to $1990-2013$ (twenty three years, See table 1). Certain consideration guided this decision. First, was the need to present a limited and manageable data; second, to present data concerning only recent inflation figures.

Table 1: Comparison of inflation rate (\%o between Nigeria and South Africa

\begin{tabular}{|l|l|c|c|l|l|c|c|}
\hline S/N & Year & Nigeria & South Africa & S/N & Year & Nigeria & South Africa \\
\hline 1 & 2013 & 8.5 & 5.7 & 13 & 2001 & 18.9 & 5.7 \\
\hline 2 & 2012 & 12.2 & 5.4 & 14 & 2000 & 6.9 & 5.3 \\
\hline 3 & 2011 & 10.8 & 5.3 & 15 & 1999 & 6.6 & 5.2 \\
\hline 4 & 2010 & 13.7 & 4.3 & 16 & 1998 & 10.0 & 6.9 \\
\hline 5 & 2009 & 11.5 & 7.1 & 17 & 1997 & 8.5 & 8.6 \\
\hline 6 & 2008 & 11.6 & 11.5 & 18 & 1996 & 29.3 & 7.4 \\
\hline 7 & 2007 & 5.4 & 7.1 & 19 & 1995 & 72.8 & 8.7 \\
\hline 8 & 2006 & 8.2 & 4.6 & 20 & 1994 & 57.0 & 8.9 \\
\hline 9 & 2005 & 17.9 & 3.4 & 21 & 1993 & 57.2 & 9.7 \\
\hline 10 & 2004 & 15.0 & 1.4 & 22 & 1992 & 44.6 & 13.9 \\
\hline 11 & 2003 & 14.0 & 5.9 & 23 & 1991 & 13.0 & 15.3 \\
\hline 12 & 2002 & 12.9 & 9.2 & 24 & 1990 & 7.4 & 14.3 \\
\hline
\end{tabular}

Sources: World Bank Data Base 


\section{Analysis of inflation rates}

As we pointed out in the literature, the major objective of Nigeria's monetary policy is the maintenance ofmacroeconomic and price stability. By definition, price stability in Nigeria refers to the achievement of a single-digit inflation rate on an annual basis (Nnanna, 2001). As shown in Figure 1 below, the achievement of this objective has not been on regular basis. For instance, between 1990 and 2000, this objective was achieved only four times 1990, 1997, 1999 and 2000). The high inflation episode observed between 1991 and 1996 re-emerged in 2001 and lasted till 2005. But inflation control during the decade of 2000 was far better than during the 1990sas inflation as it hovered between $5.4 \%$ and $18.9 \%$ compared to $6.6 \%$ and $72.8 \%$ during the 1990 s. Beginning in 2011 , the monetary policy seems to be achieving some measures as the inflation rate dropped from $13.7 \%$ in 2000 to $10.8 \%$ in 2011 and dropped further to a single digit (8.5\%) in 2013.

\section{Fig 1: Inflation rate (\%)}

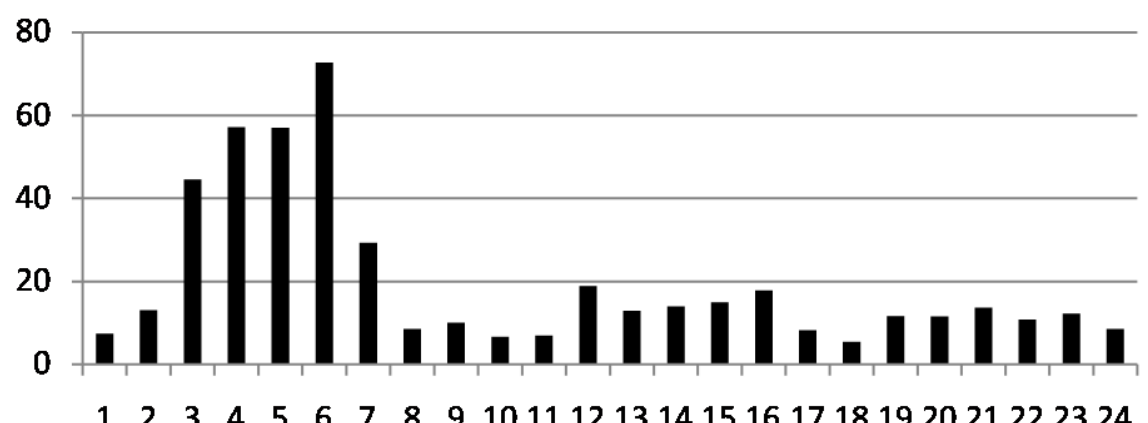

\section{Comparison of inflation rate (Nigeria vs. South Africa)}

A consistent drop (except for 2002 and 2008) in the inflation rate of South Africa has been observed since 1997. The high inflation episode recorded between 1990 and 1992 had started to decline by 1993. Since then the country recorded single digit inflation until 2008 when the rate rose to $11.5 \%$. But it was not for long as the rate for 2009 dropped to $7.1 \%$ and has consistently remained around $5 \%$ between 2011 and 2013 (Fig. 2).

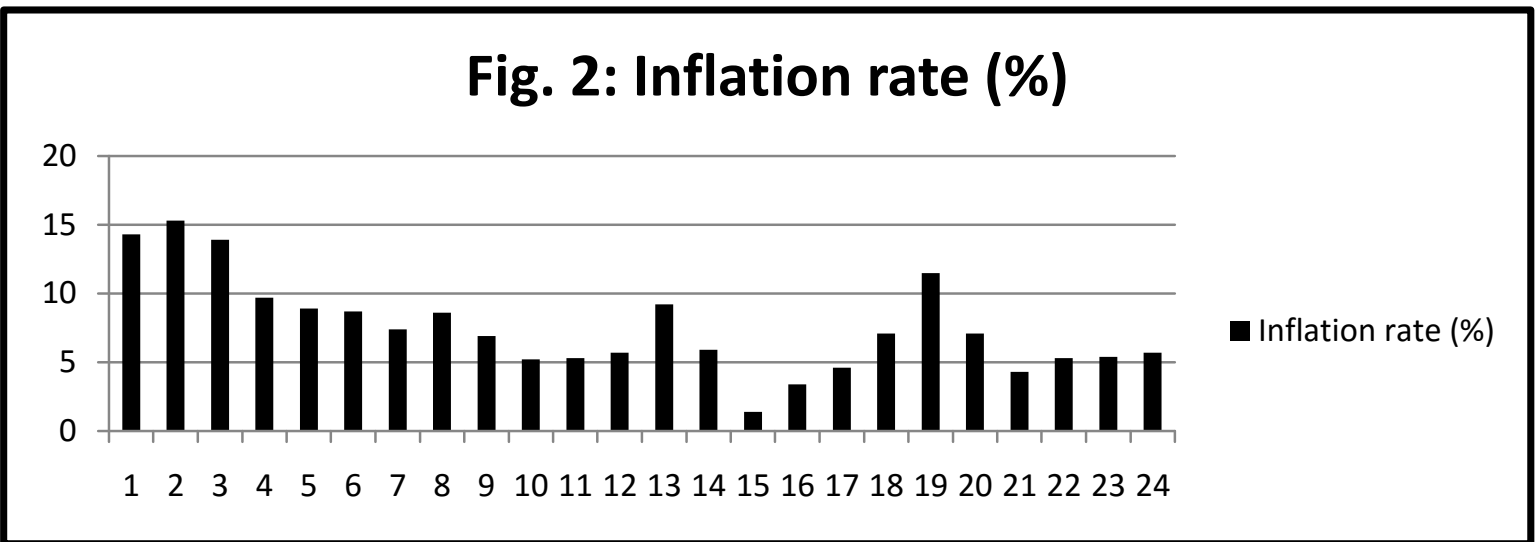

When the inflation performance of Nigeria is placed side by side with that of South Africa, we noticed that during the twenty four years under review, Nigeria achieved a single digit inflation rate seven times (1990, 1997, 1999, 2000, 20062007 and 2013), while South Africa had consistent single digit 
inflation rate, except for 1990, 1991, 1992 and 2008). According to the Index of Economic Freedom (2006), Nigeria weighted average annual rate of inflation was $14.48 \%$ between $1995-2004$, while that of South Africa for the same period was 3.30\%. The interpretation of this is that while inflation rate in Nigeria is considered to be high, that of South Africa is low. Several factors may have accounted for the differencesas the the Index of Economic Freedom take cognizance of both structural factors (corruption, tariff barriers to trade, fiscal burden, regulatary burdens on business) and monetary policy (including restrictions on banks regarding financial services, such as selling securities and insurance, etc) into consideration. But judging by the financial crisis of 2008, both countries were able to manage their inflation rate at about 12\% (see figure 3); for Nigeria, this was inspite of the hike in petroleum product price and flooding that affected agricultural outputs last during the year, which exerted inflationary pressure. It suggests a serous committment on the implementation of the financial policy.But while South Africa was able to control their inflation and secured much lower rate beyond the World economic crisis period, Nigeria's inflation rate increased to $13.7 \%$ in 2010 and declined to 12.2\% in 2012. The fact is that despite the fluctuation in the inflation pattern in Nigeria, both countries exhibite a great reduction in inflation rate in recent years compared to the early decade of 1990 . The fluctuation in Nigeria suggests the thwarting impact of structural factors of monetary policy.

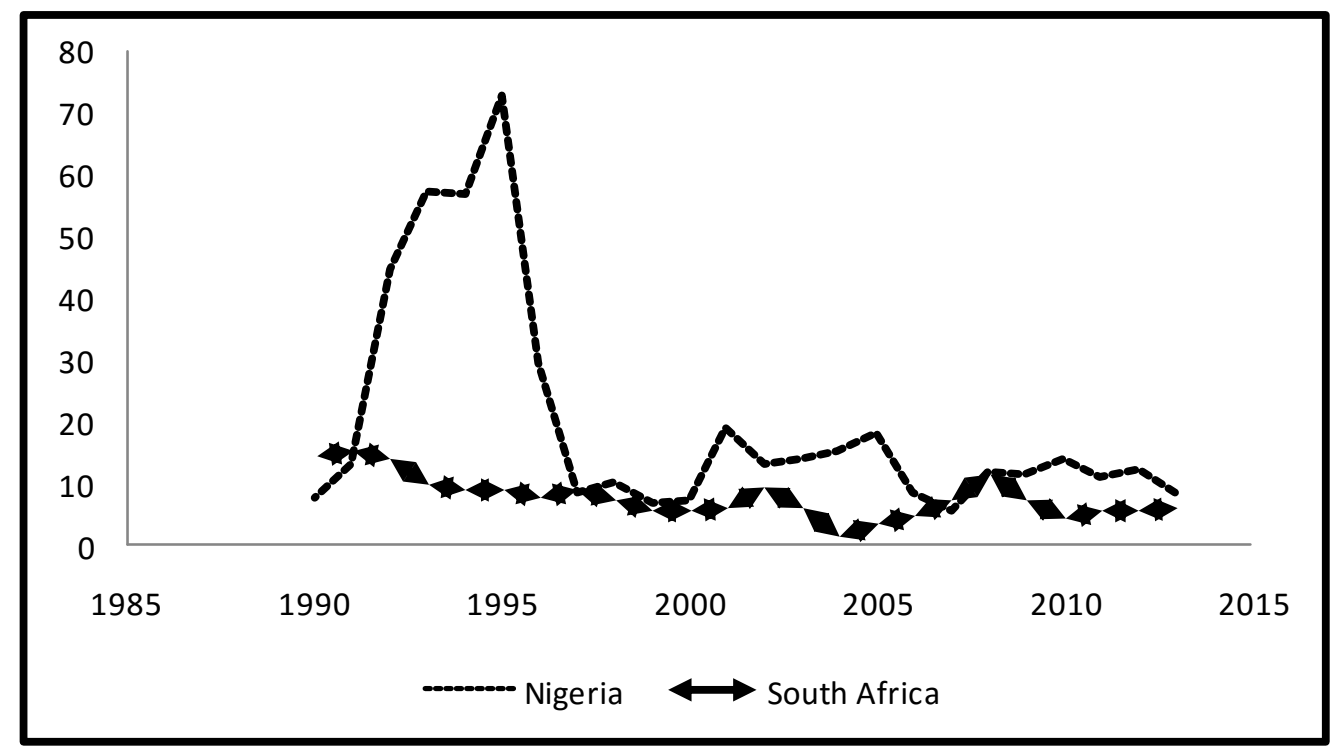

Fig. 3: Comparison of inflation rate (Nigeria vs. South Africa)

\section{Discussion}

The legal backing for monetary policy by the Bank of Nigeria is derives from the CBN Act of 1958 (as amendment by the CBN Act of 2007). Since the coming into effect of this Act, inflation targeting and exchange rate policy have dominated CBN's monetary policy focus based on assumption that these are essential tools of achieving macroeconomic stability (Aliyu\&Englama, 2009).In the early 1990s, monetary policy was guided by direct control policy. Consequently, the monetary authority imposed quantitative interest rate andcredit ceilings on the deposit money of banks, and prescribed sectorial credit allocation to the varioussectors of the economy. After the CBN's amended Act, (2014) monetary instrument shifted emphasis from growth and developmental objectives to price stability (Ebiringa, et al 2014), with the aim of fast tracking economic reform programmes and provide enabling financial system infrastructure and environment to support sustainable economic growth. All these are not without consequences. 
As shown in our analysis, the inflationary episode that occurred in 1992 persisted through the end of 1996 with a peak of $72.8 \%$ in 1995 . This period was driven by an expansionary monetary policy that promoted fiscal deficit and money supply growth. Unfortunately the authority was unable to contain the growth of private sector domestic credit and bank liquidity. The contracting monetary measure that followed in 1996 prompted declined in the inflation rate of the following year to $8.5 \%$, but this was to rise to $10 \%$ in 1998 due perhaps to electioneering campaigns and election of the period.

In 1999, the Obasanjo administration introduced series of economic reforms which concentrated on reducing fiscal deficit, tightening monetary policy, exchange rate adjustment, trade liberalization and civil service reforms. The debt reduction policies from 1999-2007 helped in reducing the hike in the inflation rate, although poor budgetary discipline did not allow the achievement of a single inflation digit except in 1999, 2006 and 2007. Corruption and death of infrastructures throughout his period, and the inability of local industries to work at full capacity opened the door to imported inflation. Comparatively during the period, the Consumer Unity and Trust Society (CUTS, 2002) reported a remarkable improvement about the South African economic reforms which did not only enhance foreign direct investment (FDI), but also resulted in massive employment. FDI flow was documented in the area of telecommunication, energy and oil, motor and components, food and beverages and hotel, leisure and gaming. Inspite of the high rate of crime, South Africa was reported as a unique destination for investors. Lower transport prices were enough to offset a rise in cost of housing and utilities.

By 2008, Nigeria inflation performance had increased from 5.4\% in 2007 to $11.6 \%$. Analysts blamed it on the inability of the authority to maintain fiscal discipline and bring down the current increase in national debt (Taylor, 2004). Higher domestic borrowing has been incurred to finance the security sector. The consequences is that borrowing by government can crowd out private sector borrowing and makes the cost of borrowing higher due the increased in the interest rate in the economy(Onyeinu, 2012). In this circumstance the Keynesian had warned that expansionary policies could made inflation uncontrollable.

The 2011 monetary policy increased the marginal policy rate (MPR) from 9.25\% to $12.0 \%$ in order to increase the rate at which Nigerian Commercial banks lend to the public for the purpose of promoting investment and encourage credit creation. Equally, the cash reserve ratio (CRR) was increased from $4.0 \%$ to $8 \%$. These rates were maintained in 2012 with a minimum liquidity ratio of $30.0 \%$. When Ajayi and Atanda (2012) reviewed the performance of the MPR of 2011 and 2012, they reported a relatively high liquidity especially in the second halve of 2012 following increase in the crude oil prices and the monetization of part of the proceeds of the excess crude oil account. This performance, perhaps, influenced the tight monetary policy stance and somewhat manageable fiscal spending adopted in 2013. These policies aided a benign inflation rate, relatively stable exchange rate, and moderate GDP growth rate (Rewane, 2014). The year was earmarked as a year of fiscal prudency, with a budget proposing a decline in fiscal deficit to $1.85 \%$ (from $2.85 \%$ in 2012), a reduction in domestic borrowing to N577bn (from N744bn in 2012) and a decline in recurrent expenditure to N2.38trn (from N2.43trn in 2012). These moderate fiscal expenses may have exerted positive impact on the external reserves which remained at a sustainable level despite the decline in oil production during the year, a low an inflation rate that declined from $12.2 \%$ in 2012 to $8.5 \%$ in 2013.

However, Rewane (2014) observes other factors that must have helped in the realization of moderate spending and inflation rate. According to him, there was absence of reported cases of flooding compared to previous years. Beside this the insurgency situation in the Northern part of the country was restricted from escalation and contained into only two states. Additionally, Nigeria was insulated to a large extent from the economic crisis that rocked the advanced economies.

In his analysis, Nnanna (2001) grouped the constraints militating against the achievement of the Nigeria monetary policy into six. These include fiscal dominance, liquidity overhang, oligopolistic 
banking system, dualistic finance and products market, data, and inefficient payments system. Government fiscal operations, especially, the inflationary financing of large budgetary deficits and the monetization of deficits, pose serious challenges to monetary management. Added to this is varied nature of liquidity in the economy. This is linked to the fact that a large informal credit market exist in the country, which constrained monitoring of money in circulation. Very few large banks also control the preponderanceof money in the banking system. The poor quality of data also affects the formulation of monetary policy. Until recently the payment system in the country was predominantly cash. This increases the volume of currency in circulation, which rendersmonetary control difficult, if not impossible.

In line with the arguments of the Structuralists, monetary policies may not entirely mitigate inflationary drivers in the economy because other factors that trigger inflation exist that do not fall within the scope of monetary policies. For instance, the election year is here, apart from the Independent National Electoral Commission (INEC) demanding for much money to spent on conducting the elections, politicians would spend money gotten from sources other than known financial intermediaries. Beside this violence associated with elections is likely to spring up in several states, which will require increased spending on security intervention. All these increase the amount of on money in circulation, and hence inflation.

\section{Suggestions toward mitigating inflation in the economy}

In order to curtail inflationary pressure on the economy both neoliberal/monetarists and structuralists observation on the causes of inflation should be taken into consideration. This suggests that while implementing the monetary policy, governemnet should complement it along with other financial regulation and programmes that would help stabilize the economy. Such regulation and programmes include.

i. Provision of public public infrastructure that would aid real sector productivity and make the economy less susceptible to global macroeconomic volatility.

ii. Effective prosecution of the war against corruption.

iii. Perfection of the cash-less economy programme

iv. Creation of Single Treasury Account (STA) intended to close leakages especially leakages linked to revenue accruable to government through the MDAs and remittance to the State government and MDAs.

v. Adoption of a unified exchange rate or what Rewane (2014) called "dollar certificates" for the dollar revenue. This would not only give us a relief from the destabilizing burden of excess liquidity but would make it unnecessary for government to borrow its own idle fund with the commercial banks at embarrassing high interest rates.

\section{Conclusion}

The main objective of the paper was to assess the objective of the Nigeria monetary policy. In doing this we decided to assess the efficacy against a pool of available data on inflationary performance of monetary policy. This was based on the realization that performance of Nigeria's monetary policy framework can be assessed according to the extent to which the actual growth in monetary aggregates, GDP growthrate and inflation, meet the policy targets. Inflation rate remains a yardstick for which price stabilization can be gauged. Relying on the theoretical standpoint of the Keynesians and the Structuralists, we argued that implementation of the monetary policy alone may not help in the realization of the monetary policy objectives. 
In order to assess the extent to which monetary policy objectives have been achieved in Nigeria, we harvested inflationary performance of the economy from the World Bank records for twenty four years (1990 - 2013) and assess it against achievement of single digit inflation. Thereafter we compare the inflationary performance with that of South Africa within the same period. We realized that inflationary pressure on the South African economy was lower than that of Nigeria, even when both countries face high inflation episode during the early decade of 1990. Although Nigeria appeared to be achieving the target of the monetary policy (single inflation digit) in 2013, we observed that existing structural constraints can still mitigate against realization of the target in subsequent years. Base on this realization we make recommendations.

\section{References}

Adeoye, B.; Ojapinwa, T. V. and Odekunle, L. A. (2014). Monetary policy framework and 'pass-through' in Nigeria: A Missing ring. British Journal of Arts and Social Sciences. Vol. 17, no. 1, pp. 14-32.

Ajayi, I. (1999). Evolution and Functions of Central Banks.Central Bank of Nigeria Economic and Financial Review. Vo. 37, No. 4, pp. 11-27.

Ajayi, F. O \&Atanda, A.A. (2012).Monetary policy and bank performance in Nigeria: A two-step cointegration approach. African Journal of Scientific Research, Vol. 9, No. 1, pp: $462-476$.

Alade, S. (2003). Fiscal adjustment in Nigeria: Issues in capital expenditure.The Bullion. 27(2): 8-16.

Aliyu, U. R. \&Englama, A. (2009). Is Nigeria ready for inflation targeting? Journal of Money, Investment and Banking. Issue 11, pp. 27-44.

Altman, E. (2003). Valuation, loss reserves and the pricing of corporate bank loans.Journal of Commercial Bank Lending, 5: 8-25.

Borio, C. (1995, April).The structure of credit to the non-government sector and the transmission mechanism of monetary policy: A Cross-Country Comparison.Bank for International Settlement Working Paper, Basle.

Busari, D., Omoke, P \&Adesoye, B. (2002). Monetary policy and macroeconomic stabilization under Alternative exchange rate regime: Evidence from Nigeria.Mimeo.

Chuku, A. C. (2009). Measuring the effects of monetary policy innovations in Nigeria: A structural vector autoregressive (svar) approach.African Journal of Accounting, Economics, Finance and Banking Research Vol. 5.No. 5. 2009.

Enahoro, J. A., Jayeola, O \&Onou, D. P. (2013).Monetary policy regime in Nigeria.Asian Economic and Financial Review, 3 (1): $62-74$.

Fasanya, I. O.; Onakoya, A. B. O \&Agboluaje, M. A. (2013). Does monetary policy influence economic growth in Nigeria? Asian Economic and Financial Review. Vol. 3, No. 5, pp. 635-646.

Fischer, S. (1997, March).Central banking: The challenges ahead for financial system soundness. Finance and development, 34(1): $14-16$.

Forder, J. (2004, December).Creddibility in context: Do central bankers and economists interpreter the term differently? (pdf) Econ Journals Watch. 
Friedman,B. M (2001). Monetary policy: Abstract. International Encyclopedia of the Social and Behavioural Science, pp.: 9976 - 9984.

Johnston, R.B. (2009). Monetary control procedures and financial reforms: Approaches, issues and recent experiences in developing countries. IMF Working Papers, WP/89/48.

Ikoh, M. U. (2010, November 9). Policy management and reforms.Being a paper presented at the training on Public Service Management Reforms for Director in Akwalbom State Civil Service, Uyo.

Mankiw, N. G. (2002). Money supply and money demand. Macroeconomics (5th ed.). Worth. pp. 482489.

Miles, M. A., Holmes, K. R. \& O'Grady, M. A. (2006).Index of economic freedom: The link between economic opportunity and prosperity. Washington \& New York: The Heritage Foundation \&The Wall Street Journal.

Ndekwu, E.C. (2005). Monetary policy and the liberalisation of the financial sector' In A. Iwayemi (Ed.).Macroeconomic policy issues in an open developing economy. (pp.: 56 - 79) Ibadan, Nigeria: NCEMA.

Nnanna, O. (2001, July) The monetary policy framework in Africa: The Nigerian experience. Paper delivered at the South African Reserve Bank, Workshop, Prestoria. Available at :www2.resbank.co.za/internet/publication..../Nigeria.pdf. Assessed: 5:10:2014.

Okigbo, P., (2008). Nigeria's financial system: Structure and growth, Ibadan: Longmans.

Oliner,S.\&Rudebusch, G. (1995).Is there a bank lending channel for monetary policy? Economic Review, No. 2 pp.3-20.

Omotola, A. H (2013, Nov, 28). The New Economy: Inflation vs monetary policies, measuring CBN's performance category.Nigeria Economy.Proshare Project Research.

Onyeiwu, C. (2012). Monetary Policy and Economic Growth of Nigeria.Journal of Economics and Sustainable Development Vol. 3, No. 7. Available at: www.iiste.org. Assessed: 7:10:2014.

Rewane, K. (2014, October 5). Monetary policy decisions.Daily Independent Newspaper, p..23

Rogoff, K. (1985). The Optimal Commitment to an Intermediate Monetary Target.Quarterly Journal of Economics, 100, pp. 1169-1189.

Taylor, J. B. (2004). Improvements in monetary policy andimplications for Nigeria.Keynote AddressMoney Market Association of Nigeria.Abuja, Nigeria, May 27. 